\title{
Comparison of the survival in the uteri of adult ewes of cleaved ova from adult ewes and ewe lambs
}

\author{
J. F. Quirke and J. P. Hanrahan \\ The Agricultural Institute, Creagh, Ballinrobe, Co. Mayo, Ireland
}

Conception and lambing rates are lower in ewe lambs than in yearlings or adult ewes (Gordon, 1967; Forrest \& Bichard, 1974). The causes of reproductive failure in ewe lambs, however, have not been determined. High ovum cleavage rates $(80 \%)$ and low implantation rates $(<40 \%)$ have been observed in Galway ewe lambs after various progestagen-PMSG treatments (J. F. Quirke, unpublished observation). It is possible that the ova produced by ewe lambs do not have the same potential for development as those from older ewes or that conditions in the reproductive tract of the ewe lamb are less favourable for survival. This report deals with the survival of cleaved ova from ewe lambs and adult ewes following transfer to the uteri of adult ewes.

\section{Methods}

A total of 141 Galway ewe lambs and 87 adult Galway ewes were used as donors. An additional 69 adult Galway ewes were used as recipients. All of the ewe lambs were spring-born and were about 8 months old at the start of the experiment. The donor and recipient adult ewes were 3-5 years old. A large pool of intact Suffolk or Galway rams and vasectomized Finnish Landrace rams were available for mating.

Oestrus was synchronized in all animals by the use of sponges containing $60 \mathrm{mg}$ medroxyprogesterone acetate (Upjohn Co.), which were inserted into the vagina of groups of donor and recipient animals on 10 or 24 October or 7 or 11 November 1975 . The mean ( \pm S.E.M.) body weight at the time of insertion of the sponges was $43.7 \pm 0.4,71 \cdot 2 \pm 1.0$ and $72.8 \pm 1.0 \mathrm{~kg}$ for the donor ewe lambs, donor adults and recipient adults respectively. The sponges remained in situ for 14 days and were removed $4 \mathrm{~h}$ earlier from the ewe lambs and recipient ewes than from the donor adults because previous experience indicated that this would ensure a closer synchronization of the onset of oestrus. All donor animals received PMSG at the time of removal of the sponges (500 i.u. for the ewe lambs and 1000 i.u. for the adults).

The ewe lambs and donor adults were each divided into two groups at random at sponge removal and run with Suffolk or Galway rams at a ratio 4-5 females for each ram. Vasectomized rams were mixed with the recipient ewes and all groups were checked for oestrus twice daily for 5 days.

The donor animals were slaughtered at a local abbatoir between 5 and 7 days after sponge removal, usually on the 4 th day after the onset of oestrus. The reproductive organs were recovered immediately and transferred to a Thermos flask which contained $0.92 \%(\mathrm{w} / \mathrm{v}) \mathrm{NaCl}$ solution maintained at $37^{\circ} \mathrm{C}$. In the laboratory the number of $\mathrm{CL}$ was counted and the oviducts and upper portions of the adjacent uterine horns were flushed for eggs with ovine blood serum. The cleaved ova recovered were stored in an incubator in blood serum at $37^{\circ} \mathrm{C}$ until transfer to the recipient ewes.

Each recipient ewe received 2 ova, one from a ewe lamb and one from an adult ewe. Ova from ewe lambs which had been mated by Galway rams were matched with ova from adult ewes mated by Suffolk rams or vice versa. Matching of the ova in this fashion permitted identification of the source of ova which survived to term, because of the different colour markings at birth of lambs sired by rams of these two breeds. All transferred ova were at the 8-16-cell stage and were placed at the ovarian ends of the uterine horns, one ovum in each horn. Balanced numbers of ova from ewe lambs and adult ewes were transferred into uterine horns which were not associated with CL in the ipsilateral ovary. After surgery the recipient ewes were run with vasectomized rams for at least 40 days and checked daily for return to service. Records were maintained of the number of lambs born to each recipient and of the colour markings of the lambs. 
Least squares methods and G-test procedures (Sokal \& Rholf, 1969) were used in the analysis of the results.

\section{Results and discussion}

Eleven ewe lambs lost their sponges and it was not possible to remove the sponges from 2 lambs because of adhesions. There was no sponge loss from adult ewes. The oestrus and ovarian responses of the donor ewe lambs and adult donors which successfully completed the treatment schedule, together with the ovum recovery and cleavage rates, are given in Table 1 . The frequency of coincident oestrus and ovulation, silent ovulation, anovulatory oestrus and complete lack of response was similar for the two types of donor animals. The interval from sponge removal to the onset of oestrus was significantly shorter for the adult ewe than for the ewe lamb donors $(P<0 \cdot 01)$. Ova were recovered from $80 \%$ of adult donors compared with $61 \%$ for ewe lamb donors $(P<0.01)$. However, there were no significant differences between the two types of donors in the proportion of ova recovered and in the percentage of ova which had cleaved. Most of the cleaved ova ( $>94 \%$ ) from all the donors were at the 8-16-cell stage.

Cleaved ova from 40 ewe lambs and 35 adult ewes were transferred into 48 recipient ewes. Four recipient ewes returned to service 18, 19, 28 and 34 days after the onset of oestrus and a further 5 ewes proved barren. The remaining 39 recipient ewes produced lambs with a mean ( \pm S.E.M.) litter size of $1.31 \pm 0.07$. Twenty-seven ewes had a single lamb at parturition and there were 9 sets of

Table 1. Performance of donor animals and ovum recovery

\begin{tabular}{lcc}
\hline & Ewe lambs & Adult ewes \\
\hline Ewes & & \\
No. completing treatment & 128 & 87 \\
No. not responding & 4 & 5 \\
No. with 'silent ovulation' & 9 & 3 \\
No. with anovulatory oestrus & 9 & 1 \\
No. showing oestrus and ovulation & 106 & 78 \\
No. yielding ova (cleaved) & $65(55)$ & $62(54)$ \\
Ova & & \\
No. recovered & 83 & 109 \\
$\%$ Recovered & 51.2 & 45.4 \\
$\%$ Cleaved & 85.5 & 78.0 \\
Ovulation rate* & $1 \cdot 51 \pm 0.08 \dagger$ & $3.07 \pm 0.24 \dagger$ \\
Interval to onset of oestrus* $(h)$ & $39.2 \pm 1.5 \dagger$ & $34.9 \pm 1.6 \dagger$ \\
\hline
\end{tabular}

* Of the animals which experienced oestrus and ovulated.

$\uparrow$ Mean \pm S.E.M.

Table 2. Survival of cleaved ova, periods of storage before transfer and synchrony of onset of oestrus of donor and recipient ewes

\begin{tabular}{lcc}
\hline & Ewe lambs & Adult ewes \\
\hline No. of ova transferred & 48 & 48 \\
No. of lambs born & 35 & 16 \\
Period from slaughter to ovum recovery (min) & $87 \pm 4^{*}$ & $93 \pm 4^{*}$ \\
Period from ovum recovery to transfer (min) & $127 \pm 9^{*}$ & $125 \pm 10^{*}$ \\
Period from slaughter to transfer (min) & $218 \pm 10^{*}$ & $218 \pm 9^{*}$ \\
Synchrony of donor and recipient & & \\
Absolute synchrony & 19 & 19 \\
\pm 0.5 days & 18 & 19 \\
\pm 1.0 days & 9 & 9 \\
\pm 1.5 days & 2 & 1 \\
\hline
\end{tabular}

* Mean \pm S.E.M. 
twins; 23 of the 27 singletons were the progeny of adult ewe donors. Of the transferred ova, 16 of the 48 from ewe lambs $(33.3 \%)$ and 35 of the 48 from adult ewes $(72.9 \%)$ were represented by lambs at term and this difference was highly significant $(P<0.01)$.

The mean periods of storage of ova (Table 2 ) and the degree of synchronization of donors and recipients were similar for the two types of ova. For each recipient the difference between adult ewe and ewe lamb ova was computed for each of the following intervals: (1) interval from slaughter of donor to flushing of the organs for ova, (2) period of storage of ova in vitro in blood serum before transfer, and (3) total time elapsing between slaughter of the donor and transfer of the ovum. The mean of the resulting values was not significantly different from zero for any of the periods. Ovum survival was not influenced by the degree of synchronization of onset of oestrus in the donors and recipients.

The results of this experiment show that, when the conditions for survival are equal, the potential of 8-16-cell ova from ewe lambs to develop to full term is less than half that of similar ova from adult ewes. The lower capacity for survival may be inherent in the ovum itself or be the result of exposure toa hostile environment in the reproductive tract of the donor animal before collection of the eggs. It is also possible that some of these cleaved ova are not, in fact, even fertilized. Fragmentation has been observed in follicular sheep ova following maturation in vitro and transfer to the oviducts of recipient ewes (Quirke \& Gordon, 1971). Developmental abnormalities may also contribute to low survival, because over $50 \%$ of cleaved, ovulated eggs from Galway ewe lambs contain anucleate particles which are often similar in size to normal blastomeres (J. F. Quirke, unpublished observation). The presence of anucleate particles in the cleaved ova of adult ewes, however, does not preclude subsequent normal development (Killeen \& Moore, 1971).

Degeneration of embryos recovered from the reproductive tract of prepubertal calves has been observed (Onuma \& Foote, 1969; Seidel, Larson, Spilman, Hahn \& Foote, 1971), and cleaved ova from prepubertal lambs do not have the same potential for continued development when cultured in vitro as those of adult ewes (Wright, Anderson, Cupps, Drost \& Bradford, 1976). Previous observations indicate that the threshold bodyweight for puberty in the Galway ewe lamb is about $36 \mathrm{~kg}$, and the donor ewe lambs used in the present experiment $(44 \mathrm{~kg})$ should, therefore, have reached or been very close to puberty at the time of hormone treatment. The results clearly show that the ova produced by Galway ewe lambs either have an inherently low potential for development or that conditions within the reproductive tract of the ewe lamb are suboptimal and have a deleterious effect on the embryos.

We thank Mr W. Loughnane and Mr T. Lally for technical assistance and the Creagh Farm Staff for care of the animals.

\section{References}

FORReSt, P. \& BICHARD, M. (1974) Analysis of production records from a lowland flock. 2. Flock statistics and reproductive performance. Anim. Prod. 19, 25-32.

GoRDon, I. (1967) Aspects of reproduction and neonatal mortality in ewe lambs and adult sheep. $J$. Dept. Agric. Fish., Ireland 64, 76-127.

KilleEN, I.D. \& Moore, N.W. (1971) The morphological appearance and development of sheep ova fertilized by surgical insemination. $J$. Reprod. Fert. 24, 6370.

ONUMA, H. \& Foote, R.H. (1969) In vitro development of ova from prepuberal cattle. J. Dairy Sci. 52, 1085-1087.
QuIRKE, J.F. \& GoRdon, I. (1971) Culture and fertilization of sheep ovarian oocytes. III. Evidence of fertilization in the sheep oviduct based on pronucleate and cleaved eggs. J. agric. Sci., Camb. 76, 375-378.

Seidel, G.E., Larson, C.H., Spilman, C.H., Hahn, J. \& FoOTE, R.H. (1971) Culture and transfer of calf ova. J. Dairy Sci. 54, 923-926.

SoKAL, R.R. \& RHOLF, F.J. (1969) Biometry. W. H. Freeman and Co., San Francisco.

Wright, R.W., ANderson, G.B., Cupps, P.T., Drost, M. \& BRADFORD, G.E. (1976) In vitro culture of embryos from adult and prepuberal ewes. J. Anim. Sci. 42, 912-917. 